\title{
The relationship between XPD Asp312Asn Polymorphism and esophageal cancer in Chinese population: a meta-analysis
}

\author{
Dahui YU ${ }^{1}$, Daoli WU ${ }^{1}$, Chong YUAN ${ }^{1}$, Hedan $\mathrm{ZHANG}^{1}$, Wenyan CHU ${ }^{1 *}$ (D)
}

\begin{abstract}
It has been reported that xeroderma pigmentosum group D (XPD) Asp312Asn is related to esophageal cancer (EC). Nevertheless, in 12 recent years, some researchers have put forward different points of view. Thus, we aimed to investigate the relation between XPD Asp312Asn polymorphism and the risk of EC in Chinese. Related studies were searched in the databases between the beginning to October 2019. An OR with 14 the corresponding 95\% CI was carried out to appraise the relevance. There were 8 studies with 2553 esophageal cancer cases and 3091 controls in 15 this meta-analysis. Due to no heterogeneities among the selected studies of all the four genetic models, fxed-effect model was used in each genotype. There was not significant relationship between XPD Asp312Asn polymorphism and EC in overall analyses by pooled ORs and subgroup analyses stratified by geographic area and source of controls. In conclusion, there may be not association between XPD Asp312Asn polymorphism and EC in Chinese populations. Further studies about other ethnic groups are needed to confirm this conclusion.
\end{abstract}

Keywords: Chinese population; XPD Asp312Asn polymorphism; esophageal cancer; relationship.

Practical Application: By further investigating the relationship between the XPD Asp312Asn polymorphism and esophageal cancer in the Chinese population, it is concluded that there is no obvious relationship between the XPD Asp312Asn gene polymorphism and EC, so that we can learn more about the pathogenesis and causes of esophageal cancer in China Some. However, more research is still needed in other populations with different environmental backgrounds or other risk factors.

\section{Introduction}

Esophageal cancer (EC) is a kind of digestive tract tumors, of which the morbidity and mortality are very different all round the world. China is one of the regions with high incidence of esophageal cancer worldwide, and more than half of the patients with EC had locally advanced or metastatic disease at the time of visit (Jemal et al., 2011; Liang et al., 2013). However, the etiology of most cases of esophageal cancer remains unknown due to probable multifactorial mechanisms of pathogenesis. One of the most pivotal factors leading to the difference in response to $\mathrm{EC}$ is the genetic variation between patients. Consequently, there are more and more studies paying attention to the differences in the gene of EC. Thus, it is important to identify the genes that contribute to susceptibility, severity, and drug response. Among these genetic variations, the polymorphisms in xeroderma pigmentosum group D (XPD) have been most evaluated in esophageal cancer (Sung et al., 1993; Boer \& Hoeijmakers, 2000). The mutation of the XPD Asp312Asn has been extensively examined in studies on XPD polymorphisms in esophageal cancer. The potential relationships between XPD Asp312Asn polymorphism and the risk of EC remain conflicting, which may be because of the ethnic and regional differences and sample size. To decrease the effect of racial differences on EC, we carried out a meta-analysis to explore the relevance between XPD Asp312Asn polymorphism and the risk of EC in Chinese population.

\section{Samples and methods}

\subsection{Eligible studies}

The studies from beginning to October 2019 were searched in PubMed, Embase, Web of Science, the Cochrane Library, the Chinese Biomedical Database, and the CNKI databases. The following terms were used to search: ("ERCC2" or "XPD" or "excision repair cross-complementing group 2" or "DNA repair gene") and ("esophageal" or "esophagus"). The search had not been restricted in language or publication status. Inclusion criteria: (1) studies with case-control which were related to the relevance between XPD Asp312Asn polymorphism and EC; (2) studies with enough data of genotypes to assess the OR; (3) the samples only referred to Chinese individuals; (4) studies with complete data. Exclusion criteria: studies which were not original article. The potentially enrolled studies and extracted information from those studies, such as the authors' name, publication year, geographic areas, sample number, and genotype data with XPD Asp312Asn polymorphism were screened by the investigators.

\subsection{Statistical analysis}

The relevance between XPD Asp312Asn polymorphism and EC was assessed by pooled ORs and $95 \%$ CIs, which were analyzed by Z-test. The model of Asn vs. Asp, Asn/Asn vs. Asp/Asp, Asn/Asn vs. (Asp/Asp + Asp/Asn) and (Asn/Asn+ Asp/Asn) vs. Asp/Asp were examined with the esophageal cancer risk, respectively. The heterogeneity test was evaluated by chi-square 
based Q-test. OR values were pooled by using fixed-effects model without significant heterogeneity. On the contrary, the random-effects model was carried out. In addition, the sensitivity was evaluated by assessing the consistency between fixed-effects model and random-effects model. The potential publication bias was evaluated by funnel plot which was assessed by the Egger's test. Stata, version 12 (StataCorp LP, College Station, TX) was carried out to perform statistical analyses. $P<0.05$ was considered to be significantly different. Moreover, subgroup analyses stratified by geographic area and source of controls were carried out.

\section{Results}

\subsection{Characteristics of obtained reports}

Through research, a total of 92 published articles assessing XPD polymorphisms together with esophageal cancer were found. In total, 8 studies (Xing et al., 2002; Yu et al., 2004; Zhou, 2007; Wu et al., 2012; Huang et al., 2012; Wang, 2012; Li \& Sun, 2013; Zhang et al., 2014) were used in this report, which met our inclusion criteria. All the included articles were published between 2002 and 2014. At the end, 2553 esophageal cancer cases and 3091 controls for assessing the relation between
XPD Asp312Asn polymorphism and the risk of EC among Chinese were involved (Table 1).

\subsection{Results of meta-analysis}

Because there were no heterogeneities among the included studies $\left(P>0.05, \mathrm{I}^{2}=0 \%\right)$, we carried out fixed-effect model in every genotype. In overall population, the pooled results did not show a significant risk of EC with the XPD Asp312Asn gene polymorphism in the four gene models (Table 2, Figure 1). Moreover, the stratified analysis did not find an association for esophageal cancer in population-based studies and hospitalbased studies, as well as in South and North China (Table 2).

\subsection{Sensitive analysis and publication bias diagnosis}

The stability and sensitivity were used to compare the difference by using fixed-effects model and random-effects model. There were no changes in all pooled ORs. In addition, sensitivity analysis showed that our meta-analysis had good stability (Table 2). The results of publication bias indicated that the shape of the funnel plot did not show notable asymmetry (Figure 2). Besides, the Egger's test suggested that there was no marked publication bias in selected studies $(t=-0.04, P=0.970$, Figure 3$)$.

Table 1. Characteristics of studies included in the meta-analysis.

\begin{tabular}{|c|c|c|c|c|c|c|c|c|c|c|c|c|c|}
\hline \multirow[b]{2}{*}{$\begin{array}{c}\text { Author and } \\
\text { publication year }\end{array}$} & \multirow[b]{2}{*}{$\begin{array}{l}\text { Source of } \\
\text { controls }\end{array}$} & \multirow[b]{2}{*}{$\begin{array}{l}\text { Cancer } \\
\text { Type }\end{array}$} & \multirow[b]{2}{*}{$\begin{array}{l}\text { Geographic } \\
\text { areas }\end{array}$} & \multirow[b]{2}{*}{$\begin{array}{c}\text { Case } \\
\text { number }\end{array}$} & \multirow[b]{2}{*}{$\begin{array}{l}\text { Control } \\
\text { number }\end{array}$} & \multicolumn{3}{|c|}{ Case } & \multicolumn{3}{|c|}{ Control } & \multicolumn{2}{|c|}{ HWE } \\
\hline & & & & & & $\begin{array}{l}\text { Asp/ } \\
\text { Asp }\end{array}$ & $\begin{array}{l}\text { Asp/ } \\
\text { Asn }\end{array}$ & $\begin{array}{l}\text { Asn/ } \\
\text { A sn }\end{array}$ & $\begin{array}{l}\text { Asp/ } \\
\text { Asp }\end{array}$ & $\begin{array}{l}\text { Asp/ } \\
\text { Asn }\end{array}$ & $\begin{array}{l}\text { Asn/ } \\
\text { Asn }\end{array}$ & $\chi^{2}$ & $P$ \\
\hline Xing et al. (2002) & PB & ESCC & Beijing & 433 & 524 & 381 & 49 & 3 & 461 & 62 & 1 & 0.53 & 0.467 \\
\hline Yu et al. (2004) & $\mathrm{HB}$ & ESCC & Hubei & 135 & 152 & 121 & 14 & 0 & 136 & 16 & 0 & 0.47 & 0.493 \\
\hline Zhou 2007 & PB & ESCC & Hebei & 327 & 612 & 279 & 46 & 2 & 528 & 82 & 2 & 0.40 & 0.527 \\
\hline Wu et al. (2012) & PB & ESCC & Henan & 235 & 235 & 206 & 28 & 1 & 212 & 22 & 1 & 0.27 & 0.602 \\
\hline Huang et al. (2012) & $\mathrm{HB}$ & ESCC & Xinjiang & 213 & 358 & 171 & 42 & 0 & 298 & 60 & 0 & 2.99 & 0.084 \\
\hline Wang 2012 & PB & ESCC & Henan & 405 & 405 & 349 & 55 & 1 & 354 & 50 & 1 & 0.31 & 0.580 \\
\hline Li \& Sun (2013) & PB & ESCC & Jiangsu & 400 & 400 & 342 & 56 & 2 & 351 & 47 & 2 & 0.10 & 0.754 \\
\hline Zhang et al. (2014) & HB & ESCC & Henan & 405 & 405 & 349 & 55 & 1 & 354 & 50 & 1 & 0.31 & 0.580 \\
\hline
\end{tabular}

PB: population-based; HB: hospital-based; ESCC: esophageal squamous cell carcinoma; HWE: Hardy-Weinberg equilibrium. $\chi^{2}$ : Chi square value; P: P-value.

Table 2. Association of the XPD Asp312Asn polymorphism on esophageal cancer susceptibility.

\begin{tabular}{|c|c|c|c|c|c|}
\hline \multicolumn{2}{|c|}{ Analysis model } & $\mathrm{n}$ & $\mathrm{OR}_{\mathrm{r}}(95 \% \mathrm{CI})$ & $\mathrm{OR}_{\mathrm{f}}(95 \% \mathrm{CI})$ & $\mathrm{P}_{\mathrm{h}}$ \\
\hline \multirow{5}{*}{ Asn vs. Asp } & Total analysis & 8 & $1.12(0.97-1.30)$ & $1.12(0.97-1.30)$ & 0.999 \\
\hline & PB & 5 & $1.12(0.94-1.34)$ & $1.12(0.94-1.34)$ & 0.978 \\
\hline & $\mathrm{HB}$ & 3 & $1.12(0.86-1.46)$ & $1.12(0.86-1.46)$ & 0.896 \\
\hline & North China & 6 & $1.12(0.95-1.32)$ & $1.12(0.95-1.32)$ & 0.994 \\
\hline & South China & 2 & $1.14(0.81-1.61)$ & $1.14(0.81-1.61)$ & 0.654 \\
\hline \multirow{3}{*}{ Asn/Asn vs. Asp/Asp } & Total analysis & 6 & $1.48(0.57-3.83)$ & $1.51(0.60-3.85)$ & 0.962 \\
\hline & PB & 5 & $1.55(0.56-4.29)$ & $1.59(0.59-4.30)$ & 0.921 \\
\hline & North China & 5 & $1.65(0.56-4.91)$ & $1.70(0.59-4.92)$ & 0.934 \\
\hline \multirow{3}{*}{ Asn/Asn vs. Asp/Asp + Asp/Asn } & Total analysis & 6 & $1.46(0.56-3.78)$ & $1.49(0.59-3.79)$ & 0.958 \\
\hline & $\mathrm{PB}$ & 5 & $1.53(0.56-4.23)$ & $1.57(0.58-4.24)$ & 0.914 \\
\hline & North China & 5 & $1.64(0.55-4.86)$ & $1.68(0.58-4.87)$ & 0.930 \\
\hline \multirow{5}{*}{ Asn/Asn+ Asp/Asn vs. Asp/Asp } & Total analysis & 8 & $1.12(0.96-1.31)$ & $1.12(0.96-1.31)$ & 0.994 \\
\hline & PB & 5 & $1.12(0.93-1.35)$ & $1.12(0.93-1.35)$ & 0.944 \\
\hline & HB & 3 & $1.14(0.86-1.50)$ & $1.14(0.86-1.50)$ & 0.882 \\
\hline & North China & 6 & $1.11(0.94-1.32)$ & $1.11(0.94-1.32)$ & 0.980 \\
\hline & South China & 2 & $1.16(0.81-1.66)$ & $1.16(0.81-1.66)$ & 0.631 \\
\hline
\end{tabular}

ORr: Odd ratio for random-effects model; ORf: Odd ratio for fixed-effects model; $\mathrm{P}_{\mathrm{h}}: P$ value for heterogeneity test. 


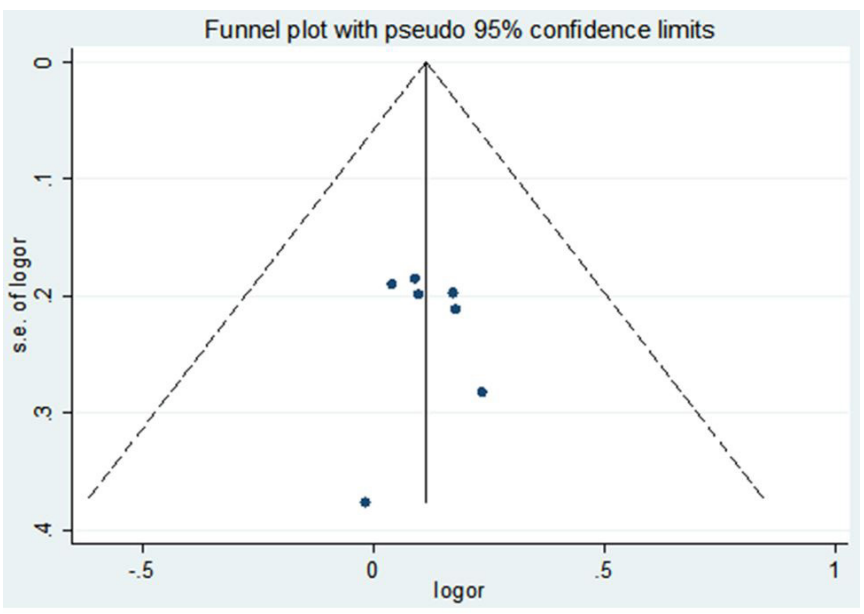

Figure 1. The forest plots on the association between XPD Asp312Asn polymorphism on esophageal cancer susceptibility under allele model.

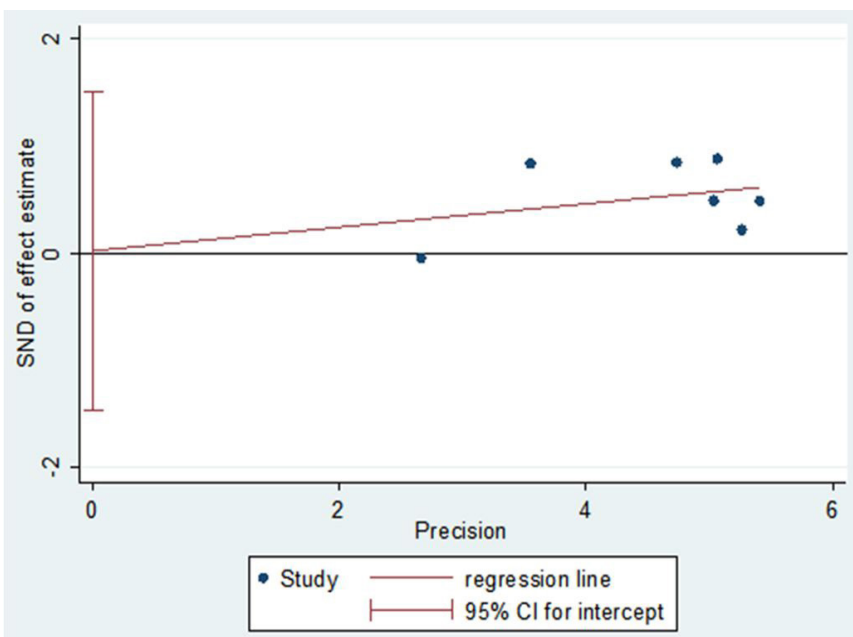

Figure 2. Publication bias assessment of XPD Asp312Asn polymorphism and esophageal cancer risk with Begg's funnel plot. SND: standard normal deviate.

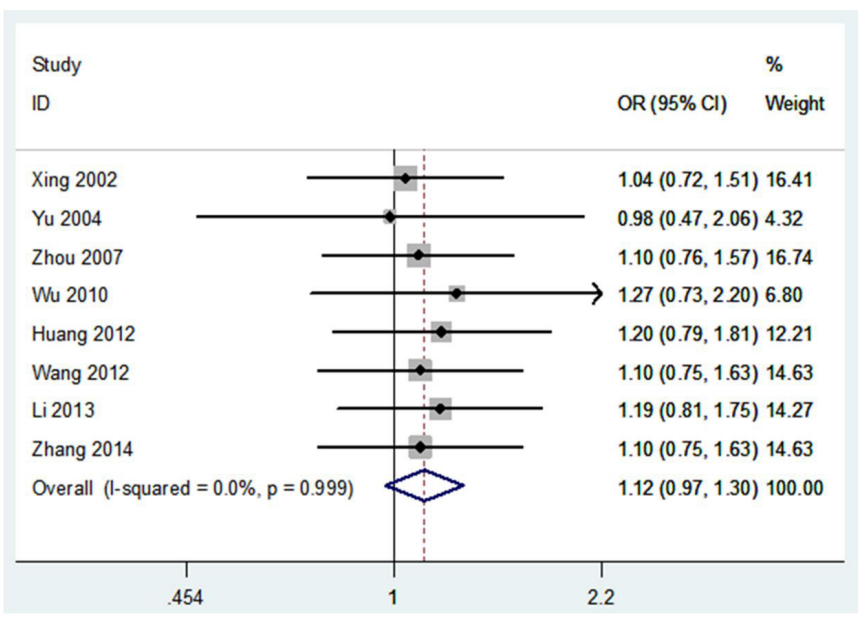

Figure 3. Egger's linear regression for the Begg's funnel plot.

\section{Discussion}

DNA repair enzyme gene polymorphisms could change the function of disrupting DNA repair, resulting in genetic variation and carcinogenesis (Coskunpinar et al., 2015). Some studies had been published to analyze the relation in XPD Asp312Asn polymorphism and EC, however, no comprehensive exact conclusion was obtained. Individual study could generate diverse results as the variability in region and individual in different populations, or due to the limit of cases. Furthermore, a unique culture and lifestyle from diverse ethnic group resulted in the different genetic trait with cancers (Zhang et al., 2018; Liu et al., 2017). To avoid these limits, we performed this study to further survey the relation about XPD Asp312Asn polymorphism and esophageal cancer in Chinese populations. Analyses of 8 publications including 2553 esophageal cancer cases and 3091 controls did not provide the evidence that XPD Asp312Asn polymorphism was related to the risk of $\mathrm{EC}$ in Chinese. And there was no marked association between XPD Asp312Asn gene polymorphism and EC in South China and North China by subgroup analyses.

Our findings were inconsistent with the other meta-analyses, which showed that XPD Asp312Asn gene polymorphism was related to a significantly raised risk for EC in overall populations (Duan et al., 2012; Guo et al., 2014; Yang et al., 2014). In Duan et al.s (2012) meta-analysis, there was notable relevance in Caucasian populations. However, Guo et al's (2014) meta-analysis found no association between them among Asian and European. In Yang et al's (2014) meta-analysis, the stratified analysis by ethnicity showed marked relationship between XPD Asp312Asn polymorphism and EC susceptibility in non-Chinese populations in the Asp/Asn vs Asp/Asp comparison and in the dominant model comparison. However, there was no similar association in Chinese. These results indicated that XPD Asp312Asn gene polymorphisms and esophageal cancer are significantly related to ethnicity. Therefore, some studies have been carried out in Chinese population and subgroups will make this meta-analysis better. Under certain circumstances, our results suggested that XPD Asp312Asn gene polymorphism may not be a marked risk factor for esophageal cancer development in the Chinese population.

Most importantly, XPD Asp312Asn polymorphism may vary greatly between different races, but this study mainly focused on Chinese population. Some limitations existed in our metaanalysis. The conducted (ethnic-specific) meta-analysis only had data from a single ethnic group, which made our results only apply to Chinese populations. Besides, we did not consider other influences on EC, such as tobacco, alcohol, environmental factors, or lifestyle, that could have led to potential bias. Furthermore, the causative mechanism of EC is much complicated and is regulated by activities of gene-gene and gene-environment interactions. Because of the lack of related information, these interactions were not included in our study.

\section{Conclusion}

In short, our results showed that there may be no relevance between the XPD Asp312Asn polymorphism and EC susceptibility in Chinese. For the sake of further assessing the relationship between XPD Asp312Asn polymorphism and esophageal cancer, more studies in other populations with different environmental background or other risk factors are needed. 


\section{References}

Boer, J., \& Hoeijmakers, J. H. (2000). Nucleotide excision repair and human syndromes. Carcinogenesis, 21(3), 453-460. http://dx.doi. org/10.1093/carcin/21.3.453. PMid:10688865.

Coskunpinar, E., Yildiz, P., Aynaci, E., Turna, A., Musteri Oltulu, Y., Hekimoglu, E., Isbir, T., \& Yaylim, I. (2015). Investigation of some DNA repair genes association in non small cell lung cancer. Cellular and Molecular Biology, 61(8), 57-62. PMid:26718430.

Duan, X. L., Gong, H., Zeng, X. T., Ni, X. B., Yan, Y., Chen, W., \& Liu, G. L. (2012). Association between XPD Asp312Asn polymorphism and esophageal cancer susceptibility: a meta-analysis. Asian Pacific Journal of Cancer Prevention, 13(7), 3299-3303. http://dx.doi. org/10.7314/APJCP.2012.13.7.3299. PMid:22994751.

Guo, X. F., Wang, J., Lei, X. F., Zeng, Y. P., Lv, X. G., \& Dong, W. G. (2014).XPD Asp312Asn polymorphism and esophageal cancer risk: an update meta-analysis based on 3928 cases and 6012 controls. International Journal of Clinical and Experimental Medicine, 7(9), 2443-2452. PMid:25356096.

Huang, C. G., Liu, T., Lv, G. D., Liu, Q., Feng, J. G., \& Lu, X. M. (2012). Analysis of XPD genetic polymorphisms of esophageal squamous cell carcinoma in a population of Yili Prefecture, in Xinjiang, China. Molecular Biology Reports, 39(1), 709-714. http://dx.doi.org/10.1007/ s11033-011-0789-z. PMid:21553048.

Jemal, A., Bray, F., Center, M. M., Ferlay, J., Ward, E., \& Forman, D. (2011). Global cancer statistics. CA: a Cancer Journal for Clinicians, 61(2), 69-90. http://dx.doi.org/10.3322/caac.20107. PMid:21296855.

Li, R. Z., \& Sun, J. (2013). Association between XPD gene polymorphisms and esophageal quamous cell carcinoma. Molecular Medicine Reports, 7(2), 674-678. http://dx.doi.org/10.3892/mmr.2012.1215. PMid:23229387.

Liang, J. E. M., Wu, G., Zhao, L., Li, X., Xiu, X., Li, N., Chen, B., Hui, Z., Lv, J., Fang, H., Tang, Y., Bi, N., Wang, W., Zhai, Y., Li, T., Chen, D., Zou, S., Lu, N., Perez-Rodríguez, R., Zheng, J., \& Wang, L. (2013). Nimotuzumab combined with radiotherapy for esophageal cancer: preliminary study of a Phase II clinical trial. OncoTargets and Therapy, 6, 1589-1596. http://dx.doi.org/10.2147/OTT.S50945. PMid:24235844.

Liu, A. X., Zheng, R. N., Yang, F., Huang, L., Zhang, L. Y., \& Zhang, J. R. (2017). Effects of curcumin on growth of human cervical cancer xenograft in nude mice and underlying mechanism. Food Science and Technology, 38(1), 106-111. http://dx.doi.org/10.1590/1678457x.02817.

Sung, P., Bailly, V., Weber, C., Thompson, L. H., Prakash, L., \& Prakash, S. (1993). Human xeroderma pigmentosum group D gene encodes a DNA helicase. Nature, 365(6449), 852-855. http://dx.doi. org/10.1038/365852a0. PMid:8413672.

Wang, L. Z. (2012). Association of tagging SNPs in ERCC2 gene with esophageal squamous cell carcinoma in Henan Han population (Master's thesis). Zhengzhou University, Zhengzhou.

Wu, X. B., Wang, P., \& Yun, Y. X. (2012). Association of XPD gene polymorphisms with susceptibility of esophageal squamous cell carcinoma in Henan province. Chinese Journal of Public Health, 28(4), 446-449.

Xing, D., Qi, J., Miao, X., Lu, W., Tan, W., \& Lin, D. (2002). Polymorphisms of DNA repair genes XRCC1 and XPD and their associations with risk of esophageal squamous cell carcinoma in a Chinese population. International Journal of Cancer, 100(5), 600-605. http://dx.doi. org/10.1002/ijc.10528. PMid:12124811.

Yang, R., Zhang, C., Malik, A., Shen, Z. D., Hu, J., \& Wu, Y. H. (2014). Xeroderma pigmentosum group $\mathrm{D}$ polymorphisms and esophageal cancer susceptibility: a meta-analysis based on case-control studies. World Journal of Gastroenterology, 20(44), 16765-16773. http:// dx.doi.org/10.3748/wjg.v20.i44.16765. PMid:25469049.

Yu, H. P., Wang, X. L., Sun, X., Su, Y. H., Wang, Y. J., Lu, B., Shi, L. Y., Xiong, C. L., Li, Y. Y., Li, F., \& Xu, S. Q. (2004). Polymorphisms in the DNA repair gene XPD and susceptibility to esophageal squamous cell carcinoma. Cancer Genetics and Cytogenetics, 154(1), 10-15. http:// dx.doi.org/10.1016/j.cancergencyto.2004.01.027. PMid:15381366.

Zhang, L. Y., Wang, F. B., \& Ren, X. B. (2018). Inhibitory effect of Dendrobium officinale polysaccharide on human gastric cancer cell xenografts in nude mice. Food Science and Technology, 38(1), 78-83. http://dx.doi.org/10.1590/1678-457x.00917.

Zhang, Y., Wang, L., Wang, P., Song, C., Wang, K., Zhang, J., \& Dai, L. (2014). Association of single nucleotide polymorphisms in ERCC2 gene and their haplotypes with esophageal squamous cell carcinoma. Tumour Biology, 35(5), 4225-4231. http://dx.doi.org/10.1007/s13277013-1553-x. PMid:24390613.

Zhou, M. R. (2007). Correlation of nucleotide excision repair gene XPC and $X P D$ polymorphisms to esophageal squamous cell carcinoma and gastric cardiac adenocarcinoma (Master's thesis). Hebei University, Hebei. 